
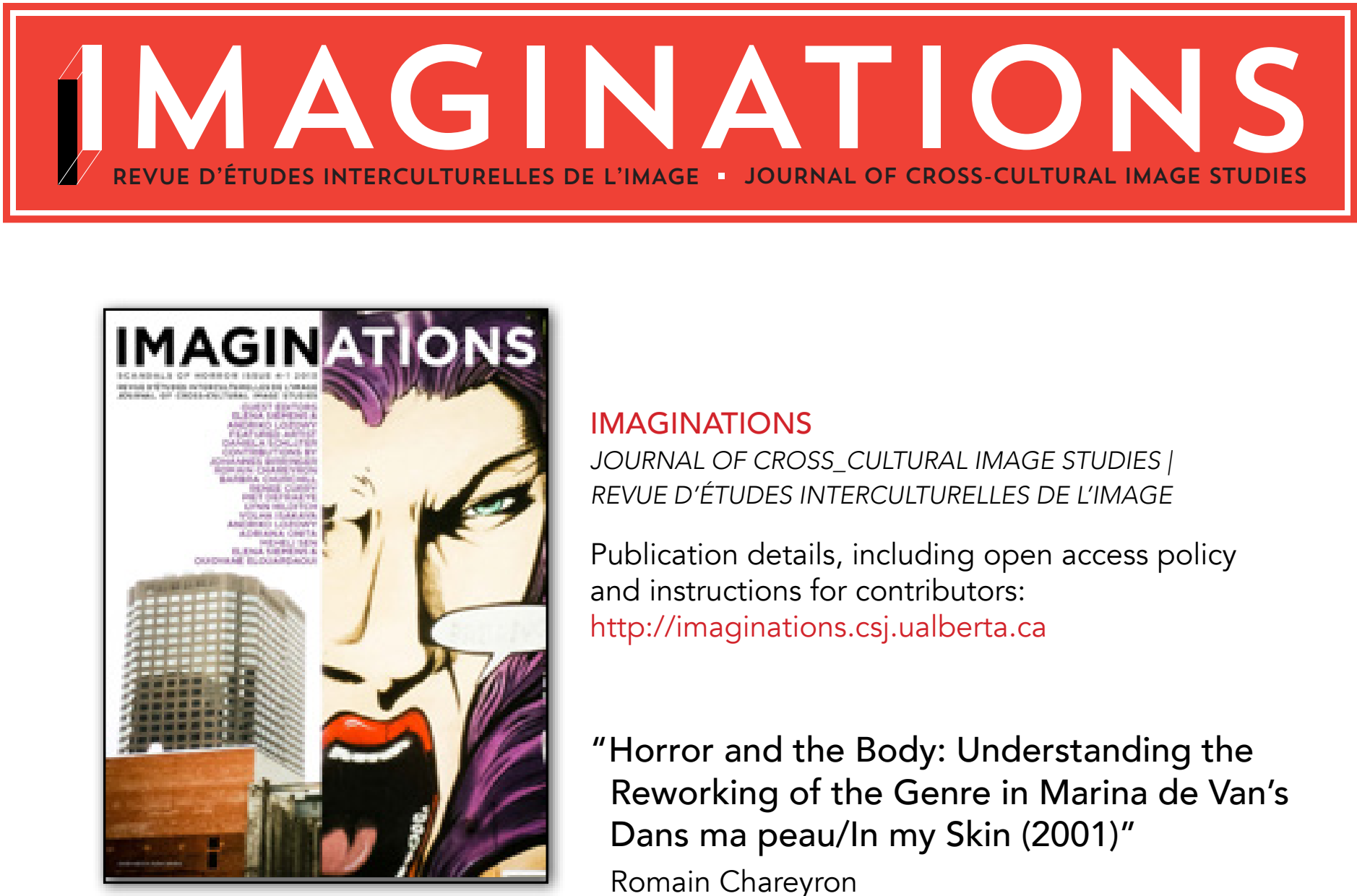

\title{
IMAGINATIONS
}

JOURNAL OF CROSS_CULTURAL IMAGE STUDIES |

REVUE D'ÉTUDES INTERCULTURELLES DE L'IMAGE

Publication details, including open access policy

and instructions for contributors:

http://imaginations.csj.ualberta.ca

"Horror and the Body: Understanding the Reworking of the Genre in Marina de Van's Dans ma peau/In my Skin (2001)"

Romain Chareyron

August 27, 2013

To Cite this Article:

Chareyron, Romain. "Horror and the Body: Understanding the Reworking of the Genre in Marina de Van's Dans ma peau/In my Skin (2001)" Imaginations 4:1 (2013): Web (date accessed) 70-81. DOI: 10.17742/IMAGE.scandal.4-1.9

To Link to this article:

http://dx.doi.org/10.17742/IMAGE. scandal.4-1.9

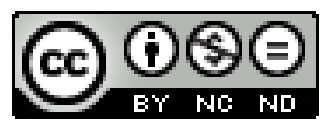

The copyright for each article belongs to the author and has been published in this journal under a Creative Commons Attribution NonCommercial NoDerivatives 3.0 license that allows others to share for non-commercial purposes the work with an acknowledgement of the work's authorship and initial publication in this journal. The content of this article represents the author's original work and any third-party content, either image or text, has been included under the Fair Dealing exception in the Canadian Copyright Act, or the author has provided the required publication permissions. 


\section{HORROR AND THE BODY UNDERSTANDING THE REWORKING OF THE GENRE IN MARINA DE VAN'S DANS MA PEAU/IN MY SKIN (2001)}

\section{ROMAIN CHAREYRON}

This article explores how Marina de Van's confrontational representation of the human body, in her film Dans ma peau/In my Skin (2001), should be understood as a reinterpretation of certain major themes in the horror genre. More specifically, I examine how de Van's mise-en-scène borrows from the genre of horror, both on a visual and a technical level, to deconstruct the meanings initially attached to the representation of the body in pain found in horror's narratives. I argue that a close analysis of the textural properties of the image allows for a reappraisal of the onscreen presence of the wounded body, this body departing from horror's straightforward visual regimen, to open up a space for the character's subjectivity to emerge. I also posit that the use of the close-up on images of blood and scars, while being reminiscent of horror's treatment of the body, becomes a vehicle for the unleashing of the character's unmediated drives to explore her own flesh and to reach a new level of selfawareness.
Cet article propose de considérer la représentation confrontante du corps humain par Marina de Van dans son film «Dans ma peau " (2001) comme une réinterprétation de certains thèmes centraux au genre de l'horreur. Plus concrètement, on montre que Van emprunte au genre de l'horreur sur les plans visuel et technique afin de déconstruire les significations liées à la représentation du corps souffrant dans le récit d'horreur. On soutient qu'une analyse approfondie des caractéristiques relatives à la texture de l'image permet une réévaluation de la présence sur l'écran du corps blessé, à partir du régime visuel de base du récit d'horreur. Cette réévaluation crée un espace où la subjectivité du personnage peut apparaître. La représentation en gros plan du sang et des cicatrices rappelle le traitement du corps dans le cadre du genre de l'horreur. On suggère ultimement que cette représentation devient un instrument pour que le personnage qui déchaîne un désir spontané d'exploration de sa propre chair afin d'atteindre une plus haute conscience de soi. 
From the moment it was released, Marina de Van's directorial debut Dans ma peau (In my Skin, 2001) has been praised as the shining example of French cinema's contentious new trend of cinéma $d u$ corps. ${ }^{1}$ Mainly interested in visceral and discomforting depictions of the human body, cinéma $d u$ corps designates "[...] a spate of recent French films that deal frankly and graphically with the body and corporeal transgressions [and] whose basic agenda is an on-screen interrogation of physicality in brutally intimate terms" (Palmer, Brutal Intimacy 57). With its uncompromising portrayal of Esther [Marina de Van], a young and successful woman whose life spins out of control when she begins to explore her body by way of self-mutilation and self-cannibalism, the film undoubtedly echoes some of cinéma $d u$ corps' main aesthetic and narrative concerns in its desire to "[push] screen depictions of physicality to unwelcome limits, raising basic issues of what is acceptable onscreen" (Palmer, "Style and Sensation in the Contemporary French Cinema of the Body" 22). If the film's unflinching representation of physicality warrants its affiliation with this new cinematic trend, it is essential to understand where this representation originates, in order to appreciate the complex visual regimen it creates as well as its impact on the images themselves and how we respond to them.

For the most part, the film's uncompromising treatment of the body in pain has been analyzed in the light of what shaped up to become cinéma $d u$ corps' "manifesto," including topics such as:
[...] dispassionate physical encounters involving filmed sex that is sometimes unsimulated; physical desire embodied by the performances of actors or nonprofessionals as harshly insular; intimacy itself depicted as fundamentally aggressive, devoid of romance, lacking a nurturing instinct or empathy of any kind; and social relationships that disintegrate in the face of such violent compulsions (Palmer, Brutal Intimacy 57-58).

The pitfall of this analysis is that it fails to acknowledge the film's most significant aesthetic achievement, namely, how it uses the horror genre as a foundation for its deeply intimate and profoundly disquieting representation of the human body. However, the references to horror never appear as a simple gimmick within the film, as the latter does not rely on the shock value that comes with the excessive display of blood or dismembered bodies, as does traditional horror cinema. My proposal is that, what defines the film's aesthetics is its constant reworking of the various visual and/or technical components of horror. In so doing, the film attempts to observe how these components can operate outside the genre's preestablished framework and generate new ways of understanding images of the body.

This article will examine how the film deconstructs horror's highly codified visual regimen in order to open up a space where the transformational capacities of the body can be fully expressed. By analyzing specifics of the mise-en- 
scène, such as the textural properties of the image and the technique of the close-up, I will argue that the narrative deconstructs the horror genre, both in its themes and its visual treatment of the body, to position the latter within a discourse of empowerment whose aim it is to challenge social norms of behavior and beauty.

"Since, for Esther, it is first and foremost a personal quest, each scar has a different meaning, which is visually conveyed by its shape and its position on the body" (Rouyer, "Style and Sensation" 29; my translation): these words come from Marina de Van herself, explaining the meaning attached to Esther's acts of self-mutilation and self-cannibalism. I chose this quotation as the main premise of my analysis, for it conveys the dual nature at the heart of the acts depicted within the narrative; if they first recall the horror genre through their explicit representation of a wounded body, the meaning of such graphic acts has to be understood as going beyond the simple desire to present us with disquieting images of violence and torture. Skin, in de Van's film, becomes the ultimate way for the character to reclaim her own body, so that flesh - the surface - gradually becomes an inscribable surface where Esther's inner turmoil and feelings - the inside - find their visual transcription.

The semantic instability of the skin is established through the opening shots of the film, with a close-up of Esther's leg, as she is seen sitting at her desk, typing on her computer. The uncanny emerges out of this familiar setting through the combined work of the lighting and the editing. The former works to bring out the materiality of the flesh, as the use of a chiaroscuro intends to show the ruggedness and the imperfections of the skin. ${ }^{2}$ In so doing, the film refuses to aestheticize the body, but instead wishes to reveal it in all its raw corporeality. Our initial discomfort is reinforced by the editing, as there is no tracking shot on the leg that would allow us to mentally "attach" it to Esther's body. Instead, the editing cuts to a close-up on Esther's face, as we see her scrutinizing the screen of her computer. Body and mind are clearly disconnected in this scene, and strangeness arises from the combined work of the close-up and the abrupt editing, as they "[...] convert a concrete entity into a decontextualized immobile surface with motor tendencies that expresses an affective quality/power" (Rogue 79). The conjoined work of the mise-en-scène and the editing serves to highlight the raw materiality of the flesh and to convey the idea that the body has a life of its own that cannot be subjected to the power of the mind. This foreshadows the shift that will occur when Esther will let her uncontrolled impulses take precedence over social rules of conduct by damaging her body, ${ }^{3}$ alienating her friends and loved ones in the process. By isolating the leg and giving the spectator an acute sense of the density of the flesh, the mise-en-scène emphasizes the textural significance of the skin. This visual device will evolve to become a central element of the representation, as we get 
to see Esther's leg covered with blood and scars, indicating the different stages of the young woman's exploration of her own body.

This initial work on the inherent strangeness of the skin is reminiscent of one of horror cinema's founding concepts that consists in revealing, through purely cinematic means, the unfamiliarity that lies at the heart of seemingly banal objects and events:

It is as if the way of presenting events would reveal the true [...] meaning of a gesture or a situation that would otherwise appear banal. This is not achieved by connecting these events to the ordinary meaning they are endowed with in everyday life, but by incorporating them within the new context of a possible world that gives them a new significance [...] (Dufour 29; my translation).

The narrative starts to question the meaning of the body and its on-screen presence through a defamiliarization process that forces us to see something common (a leg) in an unfamiliar way. Our questioning is intensified by the technique of the split-screen, which consists of showing two images simultaneously and separately on the screen. Each screen displays various urban settings (a beltway, offices) and random objects from everyday life (pens, scissors). This technique raises our awareness of the skin as being a transformable surface, and it does so by introducing the notion of "cutting" as a founding element of the representation.
This is first conveyed through the technique of the split-screen that establishes a parallel between the "skin" of the film - the reel - and the actual human skin - the epidermis - that Esther will subsequently cut. Then, the combined work of the shooting scale and the editing gives a similar significance to the objects present within the shots and Esther's leg. Consequently, we associate the close-up on the pair of scissors with the shot of the leg, the latter emerging as a surface that can be manipulated and transformed and whose significance always has to be redefined. In so doing, the representation hints at the fact that Esther's body is first and foremost defined by its potential for transformation.

If the first shots of the film use the image of the yet intact leg as a visual motif for the uncanny presence of the body on-screen, the narrative then unfolds a series of images that focus on the injured limb in order to represent the different stages pertaining to Esther's physical transformation. If these scenes might appear to tighten the connections between the film and the horror genre, they first and foremost encapsulate the narrative's intricate reworking of some of the genre's most significant topoi. The scene at the doctor's office, which takes place soon after Esther initially injured her leg at a party, constitutes an interesting example of how the film proceeds to retain some of horror's visual codes (i.e. the focus on the blood and the open wounds) while disrupting their initial meaning. In this scene, Esther's leg is perceived 
through a series of close-ups that reveal each minute detail of the gash, allowing us to see the deep scars that run along the leg, the clotted blood and the surgical suture sewn by the doctor. The unflinching display of the damaged flesh echoes the modus operandi of traditional horror narratives, since "[it] [horror cinema] corresponds to the negation of the out-of-frame and the elided. The camera invests the former so that it can fully dwell on images of horror, while the latter is denied so that death and physical pain can be felt in their duration" (Rouyer, "Entretien" 161; my translation, my emphasis). If this scene makes the body in pain the central element of the representation, it is necessary to move beyond the first impressions of shock and disgust in order to understand the raison d'être of such a visual regimen. To do so, we need to observe how the film denies the spectator visual mastery over the representation and chooses to rely on the textural significance of the image by switching from an optic to a haptic mode of vision. By unsettling our sense of perception and heightening our sensory investment within the narrative, the film disrupts any uncomplicated connection between its imagery and the horror genre, as it allows the cinematic body to exist and generate meaning beyond a normative frame, so that the character's subjectivity regulates the flow of disturbing images we are presented with.
When optic vision is based on rationality and verisimilitude between the onscreen world and the realm of human experience, haptic vision breaks this contract to pull the audience into a world ruled by feelings and sensations, rather than by human logic and the desire of mastery through the gaze. As Martine Beugnet aptly points out: "[w]hereas optic images set discrete, self-standing elements of figuration in illusionistic spaces, haptic images dehierarchise perception, drawing attention back to tactile details and the material surface where figure and ground start to fuse" (65-66). We observe a similar shift in the scene at the doctor's office; we first see Esther through a long shot that establishes a clear separation between her body and that of the spectator. Then, the different images of the wounded leg being palpated and stitched are shot in a series of close-ups from a subjective camera angle, giving the spectator the illusion of personal experience (see figs. 1 and 2).

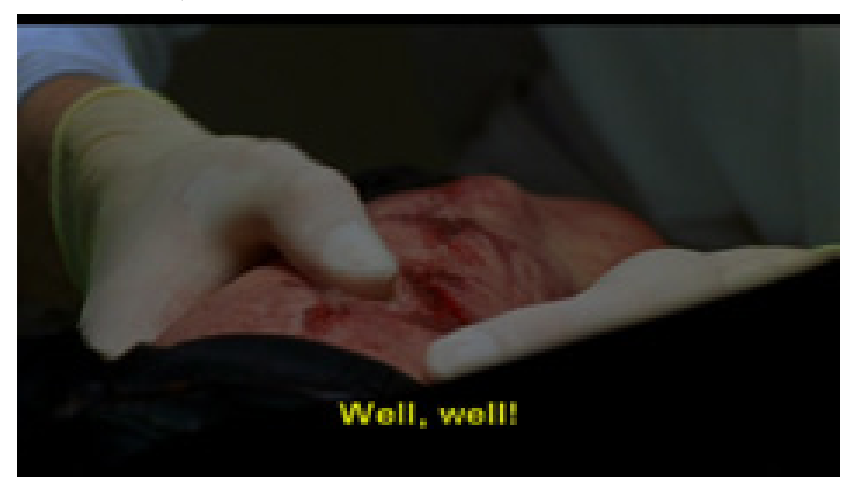

Fig. 1 "Haptic vision and spectatorial involvement." 


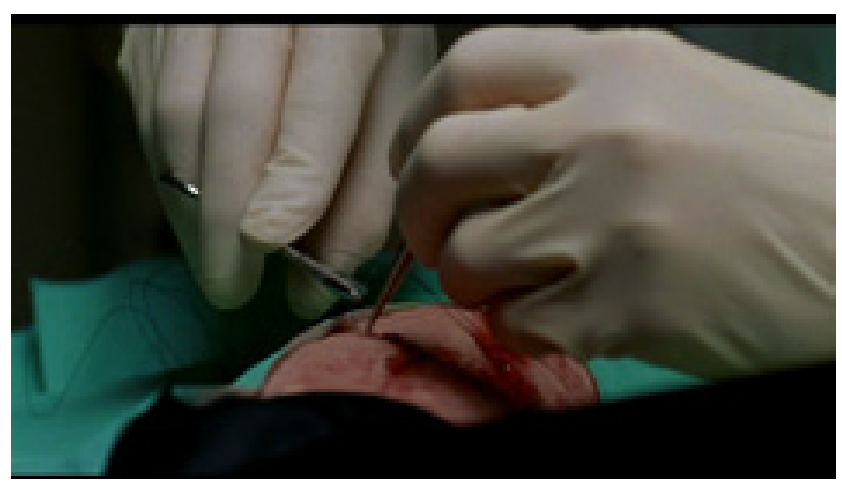

Fig. 2 "Flesh as malleable surface."

By immersing the spectator into a world of raw sensations, the mise-enscène heightens our sensory response to the images on-screen and blurs the boundary between observer and observee, forcing us to abandon our position as passive onlookers to become active participants within the fiction. Through the combined use of the close-up and the subjective camera angle, we are not simply confronted with disturbing images of the scars on the leg, as we literally come to identify with Esther. A fusion operates between spectator and character, whose aim it is to intensify the audience's physical involvement within the fiction. By relying on visual strategies that generate "[...] sensory impressions that stylistically outrun and strategically overwhelm its narrative" (Palmer, "Brutal Intimacy" 86), the film asks us to feel Esther's pain and confusion in our own body. This corporeal and emotional investment takes precedence over the sheer disgust that usually arises at the vision of injured bodies in traditional horror cinema and, as a result, forestalls any moral judgment on our behalf.
It is by enhancing the textural properties of the image and the feeling of touch within the representation that this physical involvement between the audience and the image is made possible. In so doing, the film symbolically bridges the gap that separates the spectator from the fictional space:

The viewer's skin and the film's skin allow a fleeting, incomplete kind of access to the other, which is pleasurable in its impermanence and incompletion. Their role at and as the surface of a body, as texture that both reveals and conceals, marks the fundamental affinity between the human's skin and the film's skin (Barker 49).

To achieve this, the different shots of the injured leg play on a series of opposite sensations linked to touch and the materiality of the flesh, where the smooth texture of the intact leg echoes the scars that cover the wounded one, and the red color of the bloodied leg is opposed to the pallor of the other. In the scene at the doctor's, the injured leg rather resembles a rugged landscape, and the gash can be assimilated to a deep geographical fissure, so that we are moved beyond the initial shock of horror to invest the representation and to physically experience the pain and the potential for transformation that arises out of the damaged flesh. Through the establishment of haptic vision, flesh becomes a malleable element that can be touched, cut open and stitched up in order to create something new, whose meaning cannot be intellectualized, but only felt. Any idea of moral judgment 
is deterred, as our corporeal and emotional investment takes precedence over the sheer disgust that usually arises at the vision of injured bodies in traditional horror cinema, which enables us to share Esther's sphere of experience on a deeply intimate level.

Building on this pivotal scene, the film subsequently documents Esther's escalating practice of self-cutting, the acme being reached when the young woman locks herself in a hotel room to cut and eat pieces of her skin. Whereas the scene at the doctor's office represented Esther's rather detached reaction to the vision of her wounded body, the scene taking place in the hotel room pictures Esther willingly cutting herself and transforming her own body, the latter moving from a passive form to an active force. This scene echoes horror cinema's symbolic use of the close-up, as the camera focuses on Esther's upper body, while blood from her wounds is dripping on her face. I will observe how the film uses the technique of the close-up, combined with the presence of blood and wounds, to transcribe Esther's inner urges, so that the closeup departs from the ideas of constraint and limitation usually attached to it and becomes the privileged mode of expression for Esther's uncharted exploration of her own body.

The technique of the close-up, associated with images of dismembered bodies, gaping wounds and blood is emblematic of a visual regimen whose significance can be traced back to horror and, more specifically, the subgenre of gore cinema (Rouyer, Le Cinéma gore 162). Despite its unquestionable ties to the horror genre, the representation of the body in de Van's film is not so much interested in those constituent topoi of horror that are the excessive and elaborate display of blood and wounds, as it wishes to unleash the potential for transformation and freedom that comes out of such extreme experimenting. To understand how the representation privileges the transformational power of the body over a sensational depiction of the damaged flesh, it is necessary that we focus our attention on the significance of Esther's body movements and, more specifically, on the action that consists in self-consciously harming herself (see Figs 3 and 4).

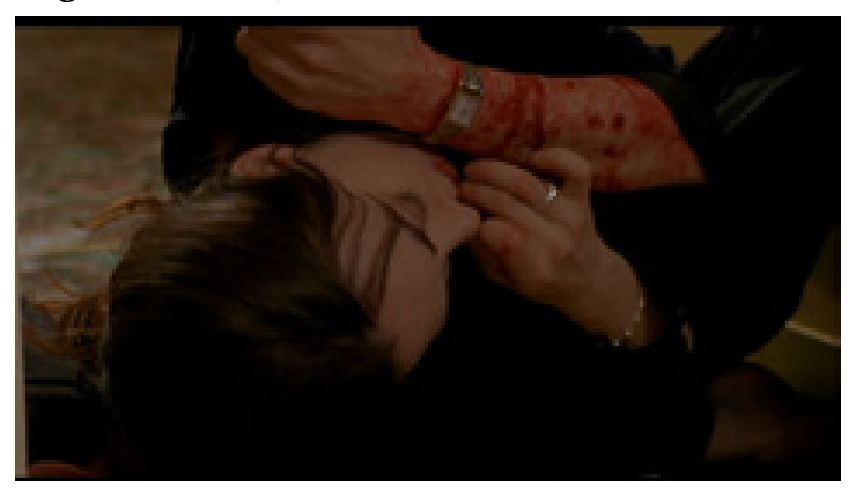

Fig. 3

"The unleashing of inner impulses.”

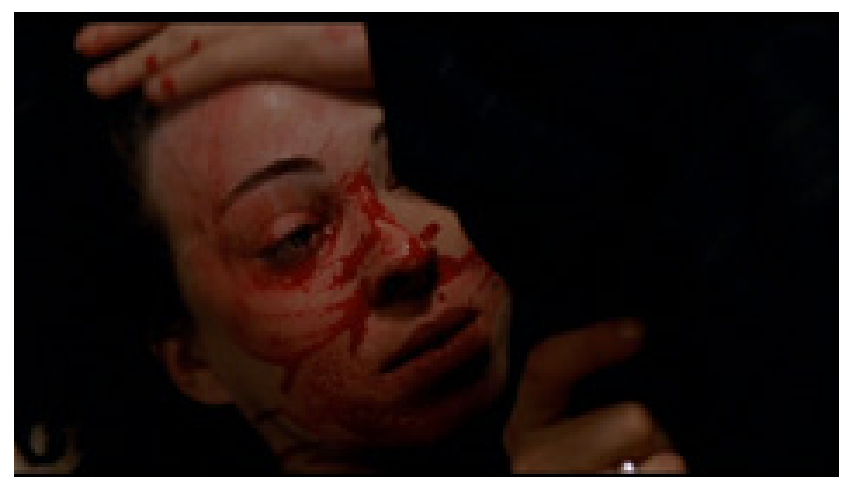

Fig. 4

"The textural implications of the image." 
In the scene that takes place in the hotel room, Esther's desire for selfempowerment finds a primary means of expression in her movements, as they symbolize her denial of a body ruled by logic and rationality in favor of a body subjected to the unrestricted drives that inhabit it. By connecting the fleeting nature of the impulses that run through the body to their visible expression at the surface of the skin, Brian Massumi's work on the concept of "affect" offers the possibility to connect the unfurling of arresting corporeal images to Esther's intimate desire to create a new identity for herself. Massumi calls "affects," or "intensities," actions that do not respond to any pre-established scheme and that are detached from any idea of logic or causality. He opposes "intensity" to what he calls "depth" and corresponds to conscious, thoughtful actions:

Intensity is embodied in purely autonomic reactions most directly manifested in the skin - at the surface of the body, as its interface with things. Depth reactions belong more to the form/content (qualification) level [...]. They [depth reactions] are a conscious-autonomic mix, a measure of their participation in one another. Intensity is behind that loop, a nonconscious, never-to-conscious autonomic remainder [...]. It is narratively de-localized, spreading over the generalized body surface, like a lateral backwash from the functionmeaning interloops travelling the vertical path between head and heart (Massumi 85).
In the film, "intensity" is first made visible through Esther's unnatural body movements and the way she occupies the space of the frame. Her body is presented as pure intensity, only guided by the unrestrained impulses that rule the frantic cutting and eating of her own flesh, as well as the contortions she resorts to and that see her in the most unlikely postures. ${ }^{4}$ The rhythm of the scene is entirely articulated around the different stages pertaining to Esther's experimentation with her body, so that the human figure no longer appears to be regulated by standard codes of behavior, but is instead perceived as an autonomous entity that has evolved to become "[...] a body passing from form to formlessness, becoming a deformed and unrecognizable entity from which, in turn, form emerges" (Beugnet 34).

The ever-changing quality of the body and the flow of images it generates are also addressed by the sensuous investment of the representation that operates through a multi-layered composition. The entire scene functions on a series of textural sensations that heighten our perception of the body's physical changes; the black pants cut by Esther first reveal the pallor of her skin which, in turn, is cut open and from which bright red blood starts dripping, which Esther then smears over her face. As a consequence, we become especially aware of the interpretative possibilities achieved through the transformation of textures and surfaces, as Esther's desire to subvert the aesthetic concept of beauty "[...] spins a series of bodily images that eradicate all sense of fixed 
corporeal limits or boundaries" (del Río 162).

The unleashing of Esther's impulses is also accompanied by a noteworthy shift in the relation between body and frame, as it appears that the former is no longer subjected to the limitations of the latter, but is shown capable of generating its own space. Again, if the focus on the numerous acts of self-inflicted torture recalls horror's fascination for the spectacle of the body in pain, de Van's film displaces the significance of the representation from the visual excess induced by such a spectacle to the potential for selftransformation that arises from this seemingly enclosed space. Consequently, the idea of entrapment and the freezing of the action usually connected to the technique of the close-up are negated in favor of the establishment of a space where the transformed body can freely express its uniqueness.

In Deleuze and the Cinemas of Performance, Elena del Río has noted that the on-screen spectacle of the female body need not be considered as the simple objectification of a character by the cinematic apparatus, but should instead be perceived as carving out a space within the fiction for the body to escape stillness and produce its own meaning by allowing subjectivity to emerge:

[...] spectacle does arrest narrative, but such arresting by no means inhibits the force of the body. If anything, it favors the unleashing of that force by freeing the body from the tyranny and the rigidity of narrative requirements. Spectacle in this sense is no longer a framed view or fetish, for it indeed becomes an actively dislocating or deforming force (del Río 33; my emphasis).

A similar process is at work in the scene where Esther is cutting and eating pieces of her skin; the frame does not constitute a limitation to the expression of the character's uniqueness anymore, but rather conveys the idea of limitless possibilities associated with corporeal transformation. This unique connection between body and frame is strengthened in another scene, towards the end of the film, where we see Esther half naked, looking at her reflection in a standing mirror. Her face and body are covered in blood and her body is shot in very unusual, animallike postures as she is seen crouching and arching her back the way a feline would. If the mirror in this scene acts as a secondary frame, its purpose is not to increase the character's entrapment within the fiction, as it usually does, but to create a space where the body can freely perform outside a pre-established frame of moral conduct.

In this respect, it is interesting to note that the vertical lines of the mirror recall the verticality that characterizes Esther's work environment, with the shots on the tall glass buildings at the beginning of the film. Whereas the introduction of verticality in these shots serves to convey the character's entrapment in a society ruled by work and social norms 
of conduct, the lines of the mirror do not enclose the body within a world of rules and regulations, but carves out a space within the fiction for the character's subjectivity to emerge and take control of the representation. In so doing, "[...] the body is shown capable of generating its own frames through its power of affection and expression [...]" (del Río 86), so that the frame does not act against the emancipation of the body but is instead an ally in its quest for seeking meaning beyond traditional means of self-expression.

This article wished to bring out the influence of horror cinema in Marina de Van's film by showing how it addresses the genre as a set of visual (the wounded body, the presence of blood and scars) and technical (the use of the close-up) elements that can be manipulated in order to lead to new interpretations of the body. In so doing, the film places the transformational capacities of the body at the center of the representation, as it presents skin as an inscribable surface whose ever-changing appearance is the visual expression of the main character's evolution and her desire to rid herself of the social and economic realities that trap her body.

If horror constitutes a visual and thematic foundation for the unsettling images that form the narrative, the article suggested that the true significance of the representation was to be found beyond the limits of the genre. Indeed, the mise-en-scène never mimics horror's codified scenarios, but instead seeks to deflect them by deconstructing some of their founding elements. Marking her body is the only way for Esther to exist in a society where "[f]lesh has become non-felt, non-experienced [and where] we have come to mistrust our senses, our passion, our inclination, our feelings [...]" (Bernas and Dakhlia 74; my translation). Because it has always considered skin as a surface that could be manipulated and transformed, horror stands as the best-suited genre to convey Esther's vital need to experiment with her body. However, with its reworking of the genre's conventions, the film is never a prisoner of this referential frame, as it generates a space within the fiction for the body's transformational powers to happen time and again. The filmed body can never be assigned a clear meaning, as it is traversed by unguarded impulses that set a variety of raw and unmediated corporeal images in motion. These images engage the spectator at a visceral level, but they never allow for a safe resolution or a finite understanding of the body on-screen. Instead, we are left amidst a world of powerful and persistent sensations, each one of them alluding to the transient nature of this body. ${ }^{5}$ 


\section{Works Cited}

Bernas, Steven and Jamil Dakhlia. La Chair à l'image. Paris: L'Harmattan, 2006. Print.

Beugnet, Martine. Cinema and Sensation: French Film and the Art of Transgression.

Carbondale: Southern Illinois University Press, 2007. Print.

Bogue, Ronald. Deleuze on Cinema. New York \& London: Routledge, 2003. Print.

Del Río, Elena. Deleuze and the Cinemas of Performance. Edinburgh: Edinburgh

University Press. 2008. Print.

Dufour, Éric. Le Cinéma d'horreur et ses figures. Paris: PUF, 2006. Print.

Massumi, Brian. "The Autonomy of Affect." Cultural Critique 31 (Autumn 1995): 83109. Print.

Palmer, Tim. Brutal Intimacy. Analyzing Contemporary French Cinema. Middletown, CT: Wesleyan Press, 2011. Print.

---. "Style and Sensation in the Contemporary French Cinema of the Body." Journal of

Film and Video 58.3: 22-32. Print.

Rouyer, Philippe. "Entretien: Marina de Van. Le corps-objet." Positif 502 (décembre 2002): 28-31. Print.

---. Le Cinéma gore: une esthétique du sang, Paris: Cerf, 1997. Print.

\section{Films Cited}

Dans ma peau. Dir. Marina de Van. Éditions Montparnasse, 2004. Film.

\section{(Endnotes)}

1 See Palmer, Tim. "Style and Sensation in the Contemporary French Cinema of the Body." Journal of Film and Video 58.3: 22-32. Print.; Palmer, Tim. "Under Your Skin : Marina de Van and the ContemporaryFrench cinéma $d u$ corps." Studies in French Cinema. 6.3 (2006): 171-81. Print.; Palmer, Tim. "In the Skin of Marina de Van." Brutal Intimacy. Analysing Contemporary French Cinema. Middletown, CT: Wesleyan. 2011: 78-88. Print.

2 In an interview she gave for the theatrical release of Dans ma peau, Marina de Van mentioned the importance of lighting in the film and explained that it played an instrumental part in the representation of the body on screen. She said: "I chose a type of lighting that would make elements stand out - what's humid or solid, what's shiny or matt which brings us back to the idea of matter (la matière)" (Rouyer, "Style and Sensation" 29; my translation).

3 In one scene of the film, Esther is seen rushing out of her office to go hide in a dark locker room of the company she works at, so that she can give in to her desire of cutting her newly sewn wound. In another scene, Esther is seen pressing a knife against her leg while at a business meeting in a restaurant, unable to resist the urge to "play" with her skin.

4 It is interesting to note that Esther's body movements in this scene act as a counterpoint to the rigid position of her body whenever we see her in her work environment. This contrast serves to highlight the two conceptions of the body that are at work within the film: the controlled and sanitized body of modern-day society and the asocial, abnormal body of unmediated drives that comes to define Esther.

5 The last shot of the film points out the impossibility to assign the body a clear meaning, as Esther is seen lying on a bed, staring blankly at the camera. The tracking out movement reinforces the uncertainty surrounding the outcome of Esther's extreme experimentation with her body. 
Romain Chareyron received his Ph.D. in contemporary French cinema and Francophone culture at the University of Alberta (Edmonton, Canada) in 2010. His research seeks to analyze the growing influence of the genres of horror and pornography in contemporary French mainstream cinema. His current research focuses on the cultural and aesthetic implications of the concept of "monstrosity" in contemporary French cinema. His work has already led to various presentations in Europe and North America as well as publications in international reviews. He currently holds a Senior lecturer position in the French and Italian department, at the University of Kansas.
Romain Chareyron a obtenu son doctorat en cinéma français contemporain à l'Université de l'Alberta (Edmonton, Canada) en 2010. Sa recherche a pour but d'analyser l'influence grandissante des genres pornographique et horrifique dans le cinéma populaire contemporain. Sa recherche actuelle porte sur le concept du "monstrueux" dans le cinéma français contemporain. Ses travaux ont donné lieu à diverses présentations en Europe et en Amérique du Nord, ainsi qu'à des publications dans des diverses revues internationales. Il enseigne actuellement à l'Université du Kansas.

Copyright Romain Chareyron. This article is licensed under a Creative Commons 3.0 License although certain works referenced herein may be separately licensed, or the author has exercised their right to fair dealing under the Canadian Copyright Act.

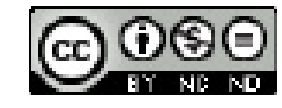

